This is an Accepted Manuscript of a book chapter for Translation and World Literature, ed. by Susan Bassnett (London and New York: Routledge, forthcoming 2017). ISBN-10: 1138641758, ISBN-13: 978-1138641754.

\title{
Two Ages of World Literature
}

Karin Littau

This essay explores how media play a constitutive role in the worlding of literature. In particular, it seeks to demonstrate how the concept of world literature around 1800, in Goethe's era, was just as medium-dependent as the concept of world literature is today Goethe coined the term Weltiteratur at a time when print was proliferating and more books were flooding the literary marketplace than ever before. His own work was caught up in this print-fever. In particular, his Werther came to epitomize this excess of print, of novels, of reading and translation. Similarly, the renewed interest in world literature that has developed over the last two decades is articulated against the backdrop of an accelerated and increasingly rich mediasphere. There is, however, a crucial difference between conceptions of world literature then and now. While Goethe's notion was importantly imbued with a sense of futurity, much contemporary debate about world literature seems to bear the sense of an ending. Similarly, while there is a sense in which Goethe considered translation as key to literary exchange and to opening up the world, translation now is threatened with disappearance by the rise of English as lingua franca and by the "pan-translatability" (Apter 2006: 232) of machine translation. This essay will set these two ages of world literature off one against each other to show that what is truly worldly about literature is neither literariness nor its untranslatability, but the various media in which the literary arts live on and find their transfiguration. 


\section{World Literature Now}

The contemporary notion of world literature is a defensive measure taken in the face of a fast changing mediascape. That it appeared with such vigour after the 1993 ACLA report is not surprising. Charles Bernheimer's suggestion there that literature's horizon be expanded by placing it firmly in a "multicultural, multimedia world" (1995: 15), and his recommendation that "comparative literature should include comparisons between media, from early manuscripts to television, hypertext, and virtual realities" (1995: 45), were, despite his claim to the contrary, repeatedly read as a move to diminish literature's importance. Peter Brook's insistence on literariness and on the study and teaching of "literature as literature and not as something else" (1995: 102) as core to the project of comparative literature is a case in point. World literature proved an attractive alternative, with the promise of a truly international multiculturalism and the long-overdue re-balancing of a Eurocentric canon that had excluded swathes of literatures around the globe. In the decade following Bernheimer's report, world literature "exploded in scope", as David Damrosch notes in the 2003 ACLA report (2006: 43), seemingly rescuing the literary from the datafication and "Disneyfication" (2014: 1) of our "postliterary age" (2013). Thus rather than countenance literature's expanded horizon in a multimedial world, as Bernheimer had proposed, the point was to raise its scale to the global and from there to the planetary (Spivak 2003) and interplanetary (Saussy 2011): literature was not going to be made smaller by other media or dwarfed by data bytes, it had to grow into a fully blown programme of world literature. But as world literature expanded as a disciplinary challenge to comparative literature, it was always already marked by a 
retreat into itself. The "comparisons with literature" that have been so central to the project of comparative literature gave way to a renewed attention, albeit through a wider lens, to the "comparison of literatures" (Saussy 2006: 23). Literature became bigger not smaller, both institutionally and spatio-temporally.

In the process world literature had to jettison a key component of comparative literature: the study of literatures in the original. The sheer scale of reading and teaching literatures from across the globe necessitated that one would need to rely on translations, since expertise in all the languages of the world is clearly not a viable option. Although it is undoubtedly a good thing to read a given text in translation than not to read it at all, critics like Gayatri Spivak pointed to the "arrogance" of assimilating the local diversities of literature from around the world into an Englishlanguage canon of world literature (2003: 73); and Emily Apter called attention to the pitfalls of a "global culture industry" that glosses over untranslatability, alterity, and incomparability to serve up pan-translated literary products to the US classroom (2013: 326). In such critiques the project of world literature is viewed as something akin to literary tourism, a flattening of the foreign linguistically and culturally and a concomitant diminishing of the scope of translation insofar as the task at hand is merely to "triangulate" some virtual original from translated versions (Damrosch 2003: 300).

Bernheimer, by contrast, expanded the remit of translation from a strictly linguistic matter when he proposed it as a paradigm for understanding media change as well as different discursive traditions, including "what is lost and what is gained in 
translations between the distinct value systems of different cultures, media, disciplines and institutions" (1995: 44). At the basis of his report was an acknowledgement that the medium of the book was in "the process of being transformed through computer technology and the communication revolution", and that since this was going to change the object of our studies, the discipline of comparative literature should therefore additionally be concerned with "the material possibilities of cultural expression" (45). Rey Chow in the same report went so far as to recommend reinventing comparative literature as "comparative media", stressing the importance of thinking about literature in terms of the media that make its storage, retrieval, and transmission possible (1995: 116). Attention to matters of mediality gives renewed and altered focus to translation precisely because the afterlives of literatures are unthinkable without mediations (editions, rewritings, refractions, adaptations, transmedia etc.) or without media (human memory, the scroll, the codex, the book, cinema, the computer, etc.). After all, books are media that are translated intramedially between editions and intermedially from one book-form to another, say from volumina into codices, handwritten codices into printed books, or now books into hypermedia. Insofar as it is not only the linguistic text but also the medial carrier that is subject to translation when works cross into other languages and cultures, this makes translation de facto part of the larger circuit of media history (Littau 2011: 277).

If we acknowledge that literature's circulation is dependent on a host of mediators such as scribes, editors, translators, booksellers, publishers, literary agents, readers, etc., and media technologies from mnemotechnics in oral culture to digital 
technologies, and that the proliferation of literature across a wide mediascape is not, nor has ever been, just book-bound or exclusively word-based ${ }^{1}$, then we must also acknowledge that literature is necessarily imbricated in a broader media history, which includes the visual arts, the performance arts, and modern screen media. In such a conception it is not sufficient merely to read literary works in a greater geographical orbit with other literary works, as Haun Saussy's "comparison of literatures" suggests, but we need "comparisons with literatures". It is for these reasons that a properly "worldly" account of the place of literature requires, perhaps more than ever, that translation be recast as not reducibly inter-lingual, but additionally interand trans-medial.

To keep literary studies apart from media studies would be tantamount, especially in this day and age, to turning our backs on what is "their shared past and necessarily entwined future" (Pressman 2014: 3). Andrew Piper's figure of the "translatologist" (2009: 239) is suggestive here since it re-envisages the humanist scholar in the age of translation and the age of media, or in an age where mediality inflects what is required of translation. Instead of compartmentalizing disciplines according to specific media and instead of "either separating or effacing the communicative difference between media", Piper's

humanist as translatologist studies the losses, breaks, ruptures, discoveries, additions, negotiations, and doublings that occur in moving from one medium to another. In this vision of the humanist, the study of literature is reconceived 
as a linguistic performance across multiple media channels, requiring something akin to Alan Liu's notion of a new "transliteracy". (239)

Transliteracy as the ability to read across an array of media platforms ${ }^{2}$ is the kind of worldly literacy that is prerequisite for understanding the changing role of literature and translation given prolific media changes. Piper's description of the work of the translatologist chimes not only with Bernheimer's comparatist but also with many of the concerns expressed in the most recent, the 2014-15 ACLA report under the editorship of Ursula Heise. Although this current report does not include a programmatic statement on the state of the discipline of comparative literature, the report's contributions feature a great many essays that address questions of technology and media head-on.

Rebecca Walkowitz, for instance, clearly takes it as a given that "we will have to approach literary works as if they exist in several languages, media, and formats" and that future modes of reading will therefore necessarily be comparative and entail that we "read more versions of works, whether editions, translations, adaptations, or rewritings" (2014/5). Similarly, Gail Finney points to a "growing interdisciplinarity" by drawing attention to "the ability of comparative literature to assimilate and nurture itself from other media, such as film and television" and additional, related fields (2014/5); and Jessica Pressman, writing in reference to electronic literature with its high density multimediality and multimodality comes to the conclusion that "We can no longer just compare texts. We must now compare textual media" (2014/5). Here, 
the mediascape is the burgeoning of something new for literature and literary study rather than a threat to its existence.

That world literature as a prominent field of study emerged in the decades between Bernheimer's and Heise's reports as a kind of redemptive undertaking to counter precisely these expansions of translation and comparative media is all too apparent when Damrosch articulates his fear that, owing to new and disruptive elements in this expanded cultural ecology, literature is becoming an "endangered species" (2013: 159). He writes: "Long novels have lost ground for years to novellas and shorter fiction, and with so many electronic attractions competing for our students' time, we may wonder whether the modern literatures are fated to disappear beneath the new-media flood" (160). Put differently, contemporary conjectures on world literature are inseparable from a perceived sense of literature coming to an end (hence also of course Damrosch's reference to the post-literary age in several of his articles).

By contrast, Goethe's conjectures on Weltliteratur are tied to a modern construction of literature, at the cusp of a distinction between Schrifttum (all kinds of writing) and belles-lettres (works of the imagination) as well as an emergent consumer literature, namely the novel. And yet, what both epochs share is that the notion of a world literature paradigm emerges at a specific media-historical juncture. In Goethe's case it was the abundance of print media (books, periodicals, etc.) and in Damrosch's case it appears to be the abundance of non-print media (internet, gaming, etc.). If print around 1800 effected a shift from "intensive" to "extensive reading" as 
historians of the book such as Rolf Engelsing (1974) have shown with the concomitant fear that the populus reads too much, in the twenty-first century, the fear is that we read too little and that there is, as Damrosch sees it, a "broad cultural shift away from books - particularly long and serious books - towards new modes of reading and newer media" (2012: 71). In both instances, the shifts in practices of reading, and indeed translating, must be explained in reference to the mediascape of the time and in both instances literature is in the process of being remade.

\section{World Literature Then}

Goethe's age spans the period when translation was taken as a marker of civilization and a constitutive element in the shaping of a German national literature. It is also the period in which translation, writing, and reading came under scrutiny more than ever. Take Johann Adam Bergk, for instance, a writer, translator, and Kant disciple from Leipzig. In 1799 he complained that "[n]ever before has so much been read in Germany than right now. The majority of readers devour the poorest and most tasteless novels with such voracious appetite, in such a way that they debase head and heart" (411-12). His outcry was directed not only at excessive reading and the genre of the novel with which, in his mind, these intemperate tendencies were indissolubly associated, but at its underlying cause: the print medium. Several decades later, the Scottish novelist and travel writer Alexander Innes Shand pinpointed the beginnings of the malaise in these same terms:

With printing and the promiscuous circulation of books the mischief that had broken out in Germany was spread everywhere by insidious contagion, like 
the Black Death of the fourteenth century. But unlike that subtle and deadly plague, it has gone on running its course ever since, and diffusing itself gradually through all classes of the community. The ferment of thought, the restless craving for intellectual excitement of some kind, have been stimulated; till now, in the last quarter of the nineteenth century, we are being driven along at high-pressure pace; and it is impossible for any one who is recalcitrant to stop himself. (1879: 238-9)

This remark is among countless during this period, stretching back to the eighteenth century that regarded the technology of print as the devil's invention. If Gutenberg was held responsible for rotting minds, as Shand did, and for a host of reading-related illnesses with medical symptoms ranging from constipation, flabby stomachs, eye and brain disorders, to nerve complaints and mental disease, it is because the quantitative increase in book production clearly had qualitative cultural-aesthetic effects: overload in material and sensory terms (Littau 2006: 39-45). The speed of production fed the rate of consumption.

In turn, the mania for books seemingly also spurred readers into becoming writers themselves. Goethe speaks of the calamity, reports Johann Peter Eckermann, "that nobody will enjoy what has been produced, but every one wants to reproduce on his own account" (Eckermann, Wednesday 20 April 1825), echoing Samuel Johnson, who half a century before had noted that "The Age of Authors" was firmly on the horizon: "there was never a time when men of all degrees of ability, of every education, of very profession and employment were posting with ardour so general to 
the press" (1753: 343). If Johnson's epitaph "All dare to write, who can or cannot read" addressed a mania for writing (a refrain which echoes contemporary critiques of the twitter and blogosphere), Alexander Pope expressed distaste for another mania and singled out for critique another kind of writer, the translator, especially the kind who would translate anything for anybody: "they'll swear they understand all the languages of the universe" (qtd. McMurran 2010: 55). The German terms most readily used in the eighteenth and nineteenth centuries to describe this array of conditions are "reading-fever" (Lesesucht) and "writing rage" (Schreibwut) (von König 1977: 89124), and their correlate, the so-called "translation-addiction" (Gottsched 1741: 516) or "translation-mania" (Engel 1879). ${ }^{3}$

Translation here is a cog in the larger machinery industrializing writing and novel-translation, part and parcel of the broader commercialization of the literary market place. In this context it is hardly surprising that the reader should be likened to a "machine" (Butterworth 1870: 501) or "animated bookcase" (Murray 1886: 517) and that the translator should be conceived as an animated object. In reference to the translation factories ${ }^{4}$ that had first sprung up in German lands in the late eighteenth century, Karl Gutzkow referred to translators as "translator-machines" (1839: 59) and Friedrich Nicolai to translation as "factory ware" (1799: 112). Indeed, translation had become so integrated in processes of print mechanization that a "translation machine" had become entirely imaginable. All that was needed, the novelist and Walter-Scotttranslator Wilhelm Hauff wrote satirically in 1827 was a "steam machine that understands French, English and German. Then, there is no need for humans 
anymore". The idea that steam drives literary translation is also picked up by Theodor Mundt in a review article on the Italian translation of Goethe's Iphigenia in Tauris 1832: 505-7). Here, translation and the steam engine are equated, since both make travel and transport possible, literally and metaphorically. More positively than critiques of the translation factory, Mundt saw steam and translation as the twin engines of cultural communication. Both can overcome the space-time continuum and both make possible the traffic between nations, cultures and languages. This "Uebersetzungs-Verkehr" (505), as he calls it, is something utterly new and peculiar in literary history.

What I have been describing up until now is, of course, part and parcel of Goethe's modernity, part of Werther-mania, and part of the media context in which Goethe first articulated the concept of world literature in 1827. Albeit scattered and inchoate, the concept is linked, as John Pizer explains, to "the technological and communicative infrastructure that enabled the rapid exchange of ideas and texts" and which "Goethe saw as the precondition for the world-literary dialogue" (2007: 11). It was prompted by reading translations from Chinese and Serbian, as well as translations of his own work into French, and it is indissociable from the movements and travels of material and symbolic goods. Here the word Verkehr, which repeatedly crops up in Goethe's writings including in the composite Weltverkehr [1827] 1840: 190), does considerable work. In German the word denotes: (a) traffic, transport; (b) contact, communication, company, (sexual) intercourse; (c) trade, service, circulation (Collins Dictionary). Verkehr thus not only refers to the "railworks, quick mails, steamships, and every possible kind of facility in the way of communication" (Goethe 
[1825] 1887: 246) that shrink the world, it also encompasses personal contact and interconnectivity through letters and visits to fellow authors, impersonal modes of communication delivered through the periodical press, newsprint, and books, commerce, trade, exchange and circulation of goods and ideas.

When Goethe wrote in 1829,

But if such a world literature develops in the near future - as appears inevitable with the ever-increasing ease of communication [Schnelligkeit des Verkehrs] - we must expect no more and no less than what it can and in fact will accomplish. (1994: 227)

It was clear that world literature was inevitable precisely because of Verkehr in all these permutations. This is to say, the German Verkehr condensed in a single word ${ }^{5}$ a sense of modernity: fast, commercial, global. English waters this down when it has to opt for just one of the several meanings of this term. The sense of modernity is at the root of the concept of world literature, and Goethean world literature as Antoine Berman notes, is "contemporaneous with the appearance of a Weltmarkt". 6 That translation plays a key role in this Weltverkehr and Weltmarkt is evident in this statement by Goethe from 1828:

And this is how we should see the translator, as one who strives to be a mediator in this universal, intellectual trade, and makes it his business to promote exchange. For whatever one may say about the shortcomings of 
translations, they are and will remain most important and worthy undertakings in world communication [Weltverkehr]. (1994: 207).

If world-literary relations were enabled on the one hand then by a concatenation of translation, the logistics of increased and faster transport links and improving communication networks, and the "untrammeled intercourse among contemporaries" (Goethe, qtd. Strich 1949: 35), those relations were also made possible, Goethe tells us, through the greater "efficiency of today's book trade" which makes "any work [] readily obtainable" (1994: 226). That the book trade and other print media play as significant a role as translation for Goethe in the circulation of literature, including his own work, is apparent in Goethe's short piece "Bezüge nach Aussen" [foreign relations]. Piper summarizes these relations and their intricacies as follows:

Goethe translated for his journal, Ueber Kunst und Alterthum, a portion of an article from the French journal, Le Globe, on the new "commerce intellectual" which was itself a translation of an article from the British Foreign Quarterly Review on Swedish literature and which had been published as a direct response to Goethe's own initial appeal for a new "world literature", we can begin to see the high degree of circularity that such cultural circulation had assumed. (2009: 14) 
The print media, including the "newspapers", "critical journals", "reviews", "dailies", and "literary magazines", all of which Goethe cites, are important vehicles for keeping readers informed about the latest literary news from abroad (1994: 225-6), they are also outlets for generating publicity. Media-savvy as he was, Goethe used the available channels of print culture to advertise his own work, announcing prequels, sequels, reprints, etc. of his novel Wilhelm Meister's Travels. Piper shows in sparkling detail just how highly evolved and "self-referential" Goethe's "publishing practices" were (Piper 2009: 30). Here is a glimpse Piper gives us of some of these machinations:

the "prepublications" of the Travels that stretched over the course of almost fifteen years and that uniformly appeared in the format of the miscellany consisted of a translation, an incomplete "book" from the novel, half of a novella, half a novella with an original preface, an incomplete novella, and then the concluding half of a novella that had appeared three years earlier in print and that had been omitted in Goethe's autobiography published even earlier. (29-30)

The publication history of the novel is so complex and convoluted that Piper provides his reader with a map to help visualize the extent of the dispersions (35). What is at stake here is the undoing of the "boundaries" (30) of this particular work as well as its repetitions across a range of print formats, all of which demonstrates, Piper shows, "a constitutive feature of the modern literary market place" (31). 
If the boundaries of what is ostensibly a single work are being undone here, The Sorrows of Young Werther - both a bestseller and world literature - is a novel that provides us with another type of undoing. Written in 1774, translated almost immediately into dozens of European languages, often more than once, and reprinted again and again, including in unauthorized versions as early as 1775 , the novel's characters migrate from one media platform to another, and were transfigured for rewrites in prose and poetry, spin-offs and parodies, for stage adaptations and the visual arts. Sometimes Werther kills himself and other times he lives happily ever after with Lotte. Much of this happened even before Goethe had a chance to publish his own revised edition. Werther-fever was part of a full-blown reading epidemic, with some readers reduced to uncontrollable fits of weeping for weeks on end, others - if Napoleon is to be believed - devouring the novel no less than seven times, others still prompted to emulate Werther and take their own lives. Werther thus became a cult, which is why the town council of Leipzig made it a punishable offense to sell the novel, and dress up in Werther's garb - a ban first enforced in 1775 and only lifted half a century later (Swales 1987: 97). That the book had reached cult status during Goethe's lifetime and had become eminently merchandisable is summarized by Peter Watson in The German Genius: "In Vienna there was a Werther fireworks display and in London there was Werther wallpaper. Meissen porcelain was designed, showing Werther scenes, and in Paris perfumieres sold Eau de Werther" (2010: 115-6). In this we see two aspects of the worldliness attaching to literature. The first is the frank concern with commerce both insofar as this facilitates the transportation and therefore accessibility of literature amongst other goods. The second, not in Goethe's gift, concerns the commercial potential of his novel identified and exploited by everyone 
from tailors to potters to perfumiers. These emphasise the worldly, i.e. non-literary context in which literatures emerge and circulate, a logistical fact that Goethe's conception of world literature celebrates as the material possibility of a genuine worldly literature.

Does this make Werther a forerunner of Star Wars with merchandise and tiein paraphernalia? And relatedly, did Goethe "predict[]" the kind of global modernity "we now inhabit", as Damrosch credits to him? (2003: 1). This depends on whether the futurity Goethe attached to his account of world literature is reducible to prediction. In other words, did Goethe predict a time when futurity would have arrived? Famously, Goethe stated in 1827 that "'National literature does not amount to much these days; the era of Weltliteratur is imminent, and it is incumbent upon everyone to work towards hastening its advent" (qtd. and transl. Frank 2007: 1511). For all Goethe's concern with logistics and commerce as the media of what he noted may constitute an emergent world literature, it was tempered by his demand that the latter's advent be hastened. We might then describe Goethean world literature - or literature's worldliness - as the intercourse of commerce and futurity.

\section{Literature's Worldliness}

Literature is worldly in the material sense. That is, Goethe is not incidentally but essentially concerned with commerce, logistics, and communications as the sine qua non of any world literature. This is not only in the trivial sense that there cannot be a world literature without large print runs and massive distribution, ${ }^{7}$ but also in the 
sense that the same technologies that facilitate accelerated communications additionally supply the material of which literature is the expression.

Just as the world-literary formation of Goethe's age depended on Verkehr in all its permutations, so changes in the nature of Verkehr over the last two centuries make ours a "second age" of world literature. This is confirmed when Joseph Tabbi, noting "the electronic ... and social networks" (2010: 26) underpinning them, suggests that recent digital literary arts "might in fact be an emerging world literature" (20). This is not to say that the second age is the future orientation of the first age realized in the second, but rather to draw attention to the agency of the Verkehr proper to each age in the realization of its own worldly literatures. If Goethe was right, and the worldliness of world literatures entails a future orientation, this will remain equally true of Tabbi's "emerging world literature" as it was of Goethe's own. The futurity is not to be cashed in, in other words, in a future present, but to be translated into a futurity proper to a future age. With this caveat in mind, let us turn to exemplars of these new literary arts Tabbi might suggest are candidates for world literature.

The electronic online works, for instance, of the artist collective Young-Hae Chang Heavy Industries (YHCHI) ${ }^{8}$ have been addressed in the context of an emerging world literature. Critics such Pressman and Walkowitz have shown the extent to which YHCHI's e-literatures comment on and enact translation in a technologized mediasphere where the Internet is a means of global circulation. These works "seem to suggest", Walkowitz notes, "that differences in geography and culture are irrelevant in an age of electronic literature" (2013: 176). Using flashing techniques derived from 
film and film-related media (e.g. photographic or tachistoscopic media), YHCHI's multilingual translation-works make visible the translation process on the screen. This makes translation not only the content of such work, but also its means of production, since translation operates not just at the level of languages (the artist duo Young-Hae Chang and Marc Voge utilize linguistic competences in English, Spanish, German, French, Korean, Chinese and Japanese), but also at the level of media, by drawing on them, whether textual, filmic, or digital, in order to make translation itself variously visible. But visibility is no guarantee of legibility. Initiating a procedure of "autotranslation", whereby a prose extract is continuously and instantaneously translated between one language and the next, both versions being presented simultaneously on a split screen, "even a reader fluent in both languages", as Pressman points out with reference to their work Nippøn, "is unable to read both texts simultaneously" (2014: 153). YHCHI's translations-in-motion fulfill and resist the dream of instant translation insofar as instantaneity is impossible to apperceive : we may perceive that a translation occurs but cannot apperceive the translation as translation. The temporal difference necessary to compare source with translation on an animated screen, unlike in printed parallel text editions, is eliminated by instantaneity. As such, their works are comments on translation as much as onscreen depictions of it in a computer age that promises that everything - including the translation process itself - can happen in an instant.

Automatic translation is also key to Warren Sack and Sawad Brooks's Translation Map (2003), ${ }^{9}$ a project that was exhibited by the Walker Art Center in Minneapolis. It critiques machine translation's supposed pan-translatability and puts 
forward an "alternative computer technology for translation" (Sack 2005: 10). As Sack explains: "computers and networks should be used to facilitate collaborative work between people, rather than as a magic black box that [Warren] Weaver's translationas-decoding problem implies". The model of "translation-as-collaboration" as an alternative to automatic translation thus uses a computer prototype system to locate human translators on the Internet, facilitating "worldwide, cross-border, multi-lingual conversations" ${ }^{10}$ and collaborative rewriting. Sack and Brooks' Translation Map is therefore part of an avant-garde genealogy of experimental writing practices, in particular the "Surrealists' exquisite corps writing games". ${ }^{11}$ A computer programme tracks the circulation of a sent message and a map visualizes the translations taking place from language to language across the globe so as to make its movement through cyberspace geographically locatable. If a message does not reach its addressee, which is a real possibility given patchy internet access across the globe, the sender is encouraged to print out the message, fold it in a pre-described way, and relay it the old-fashioned way, through the postal system.

If the Translation Map uses the Internet and the postal service for crowdsourced, collaborative translation, the project of the Spectacular Translation Machine uses the forum of the 2013 London Literature Festival ${ }^{12}$ for face-to-face collaboration. In this way it de-digitises online "translation factories" and translates them into a preand/or post-electronic village. For one weekend, the public was invited to collectively translate a book from French into English. More scriptorium than online forum, this project demonstrates the worldly community on the threshold of a realized global village. Similarly, Translation Games $^{13}$ - a project first organized in 2013 and still 
ongoing - draws together artists, designers and translators through a host of public events in London to engage in multi-medial translations. Modeled on the game of Chinese Whispers, a specially commissioned creative work was translated for the 2013 game into several languages and across different media: "from text to performance, from performance to video, from video to sculpture, from sculpture to painting, etc." and "at each stage of the language chain", the text was also translated into textiles. Translation Games has thus resulted in a range of artworks, and among others things, materialized into an "interactive flip-book catalogue". What projects of this kind demonstrate is that our traditional notions of writing, translation, making art, etc. are transforming in an age of large-scale connectability between people and interconnectivity between media platforms. Such projects are also, however, testament to translation's expanded remit in a broader media history.

If the digital sphere has prompted us to rethink writing and translation, it has also prompted us to rethink the book medium. Take Nox, first published by New Directions in 2010, which is a work of poetry and a book in a box, written by the classicist and translator of Aeschylus, Euripides, Sophocles and Sappho, Anne Carson. Nox is an objet d'art, designed in collaboration with Robert Currie, and a meditation on Carson's brother's death, based on a scrapbook she made in his memory. It is also a translation-work of Catullus's poem 101, itself an elegy to a lost brother, which Carson, we are told, has struggled to translate.

Nox is an exercise in translation as well as an exercise in media translation. The book opens with the Catullus's original poem, followed by lexical entries on each 
Latin word together with Carson's commentaries, so as to provide us with a range of meanings for each word and crucially the means to create our own translation. It ends with an illegible English translation on a crumpled, stained, and smudged piece of yellow paper. The translation, on the left-hand side of the page, remains as ungraspable as the brother's life Carson tries to stitch together from fragments and memories on the right-hand side of the page. Presenting Nox in a concertina-folded book-form arguably "marks an intermediate stage between the scroll and the codex" (Brillenburg Wurth 2013: 23). It further translates several media into one: handwritten and typed notes and letters appear alongside Xeroxed and scanned pages, photographs and drawings. By referencing ancient book-forms alongside contemporary forms of digital reproduction, the work as a whole resists reduction to a mediatic "Now". As Kiene Brillenburg Wurth has shown, while "the foregrounded presence of photoimaging in Nox makes the connection with the digital screen all too evident", there is also "resistance to the digital" (27), insofar as Carson herself is all too aware that Nox, produced in the Kindle age, is materially "un-Kindle-isable" (Carson qtd. Brillenburg Wurth: 27). If bookishness is understood here as a resistance to the digital, it is paradoxically the digital that has in effect made the bookishness possible in two senses: fear of the death of the book in a digital age has produced a host of books of late that revel in bookish materiality, and bookishness in Nox is achieved through distinctly digital means. Carson's Nox, then, is a work that thinks about books and about translation, and that demonstrates how books and translations are shaped by the media of today. Finally, it is a book that is contained in a box, but it is also a book without borders, forming part not only of an art installation at the Hampden Gallery in 
Amherst in December 2011 by Alexis Fedorjaczenko, but also part of a dance performance at the O, Miami Poetry Festival in April 2011 (Plate 2005: 106).

The worldliness of these works is immediately apparent in that they each in their own way articulate their material conditions of production while variously incorporated in or resisting incorporation into globalized communications infrastructures. For this reason, they all address translation and media translation. If worldliness in this sense is evident in these examples, so too is their implicit futurity. That is, these practices are futurable in their own terms and so neither cancel their own futurability, nor that of some communications revolution to come (the futurity proper to a coming age). New media will always change the modes of literary production and the requirements placed therefore on translation. Perhaps we will remember our fictions in the future, rather than witness them unfolding in a present?

When Damrosch suggests in What is World Literature? (emphasis added) that it is "not an infinite ungraspable canon of works but rather a mode of circulation and of reading" (2003: 5), the "what is" that frames this question jars with Goethe's futurity, because futurity by its very nature is not. Neither a canon nor graspable, world literature is emerging. And, just as literature is inexhaustible, so is the world. World literature is not graspable not just because there is too much of it (the sheer quantity Franco Moretti addresses), but because it is part of the function of literature to reimagine the world of which it is part. That is both the worldliness of literature and its futurity. How literature reimagines the world of which it is part is dependent upon the media, that is, the technical, logistical, communicative means that the world sets at its disposal. Viewed in this light, worldly literature is necessarily futural, 
because there is in principle no limit to the number of ways in which the world - an enormous engine for reimagining itself - can so reimagine itself. For example, if world literature were reduced to a mode of reading, what if literature were no longer read or seen? What if narrative were felt or partly recalled, as Pat Cadigan imagines in Fools (1992)? Finally then, the present tense in "what is world literature?" negates that literature perpetually reimagines itself and the world of which it is part.

\section{Bibliography}

Arac, Jonathan (2007) "Global and Babel: Language and Planet", Shades of the Planet, ed. by Wai Chee Dimock and Lawrence Buell (Princeton N.J.: Princeton University Press), pp. 19-38.

Apter, Emily (2006) The Translation Zone. A New Comparative Literature (Princeton N.J.: Princeton University Press).

- (2013) Against World Literature. On the Politics of Untranslatability (London: Verso).

Bachleitner, Nobert (1989) “Übersetzungsfabriken”. Das deutsche Übersetzungswesen in der ersten Hälfte des 19. Jahrhunderts, Internationales Archiv für Sozialgeschichte der deutschen Literatur (IASL) 14.1, 1-49. 
Bergk, Johann Adam (1799) Die Kunst, Bücher zu lesen. Nebst Bemerkungen über Schriften und Schriftsteller (Jena: In der Hempelschen Buchhandlung, rpt. 1966).

Berman, Antoine (1992) The Experience of the Foreign: Culture and Translation in Romantic Germany, trans. S. Heyvaert (New York: State University of New York Press).

Bernheimer, Charles (1995) "Introduction: The Anxieties of Comparison" and "The Bernheimer Report, 1993", Comparative Literature in the Age of Multiculturalism, ed. by Charles Bernheimer (Baltimore: The Johns Hopkins University Press), pp. 1-17, pp. $39-48$.

Brillenburg Wurth, Kiene (2013) "Re-vision as Remediation: Hypermediacy and Translation in Anne Carson's Nox", Image and Narrative 14.4, 20-33.

Brooks, Peter (1995) "Must We Apologize", Comparative Literature in the Age of Multiculturalism, ed. by Charles Bernheimer, pp. 97-106.

Butterworth, C. H. (1870) “Overfeeding” Victoria Magazine 14 (November to April), $500-4$.

Chow, Rey (1995) "In the Name of Comparative literature", Comparative Literature in the Age of Multiculturalism, ed. by Charles Bernheimer, pp. 107-116. 
Damrosch, David (2003) What is World Literature (Princeton N.J: Princeton University Press).

- (2006) "World Literature in a Postcanonical, Hypercanonical Age", Comparative Literature in the Age of Globilization, ed. by Haun Saussy (Baltimore: The Johns Hopkins University Press, 2006), pp. 43-53.

- (2012) "The End of the Book? Literary Studies in a Post-Literary Age, 1960/2010/2060", Rethinking the Humanities: Paths and Challenges, ed. by Ricardo Gil Soeiro and Sofia Tavares (Cambridge: Cambridge Scholars), pp. 67-86.

— (2013) "World Literature in a Postliterary Age", Modern Language Quarterly 74.2, $151-170$

- (2014) "Introduction: World Literature in Theory and Practice", World Literature in Theory (Oxford: Wiley Blackwell), pp. 1-12.

Eckermann, Johann Peter, Conversations of Goethe, trans. John Oxenford (Digital Production, Harrison Ainsworth, 2006), online at: $<$ http://www.hxa.name/books/ecog/Eckermann-

ConversationsOfGoethe.html\#contents>

Engel, Eduard (1879) "Die Uebersetzungsmanie in Deutschland", Magazin für die Literatur des Auslandes 43/44, 461-464, 677-680. 
Engelsing, Rolf (1974) Der Bürger als Leser: Lesergeschichte in Deutschland 15001800 (Stuttgart: Metzler).

Finney, Gail (2014/5) “The Reign of the Amoeba: Further Thoughts about the Future of Comparative Literature" (published online 3 July 2014), ACLA Report on the State of the Discipline 2014-2015, ed. Ursula Heise.

Frank, Armin Paul (2007) "Translation and Historical Change in post-Renaissance Europe", Übersetzung, Translation Traduction: An International Encyclopedia of Translation Studies, Volume 2, ed. by Harald Kittel, Juliane House, and Brigitte Schultze (Berlin: Walter de Gruyter), pp. 1460-1520.

Goethe, Johann Wolfgang von (1840) Goethe’s Sämmtliche Werke in Vierzig Bänden. Dreiunddreizigster Band (Stuttgart und Tübingen: Cotta).

- (1887) “Goethe to Zelter (Weimar 6 June 1825), Goethe's Letters to Zelter, selected, translated and annotated by A.D. Coleridge (London: George Bell and Sons), p. 246.

- (1994) “On Carlyle’s German Romance (1828), “On World Literature”, Goethe, The Collected Works, Volume 3: Essays on Art and Literature, ed. by John Gearey, trans. by Ellen von Nardoff and Ernest H. von Nardoff (Princeton, NJ: Princeton University Press), pp. 206-208, pp. 224-228. 
Gottsched, Johann Christoph (1741) "Nachricht über von neuen hieher gehörigen Sachen", Beyträge zur critischen Historie der deutschen Sprache, Poesie und Beredsamkeit. Band 7. Stück 27 (Leipzig: Breitkopf), pp. 512-519.

Gutzkow, Karl (1839) "Die Deutschen Uebersetzungsfabriken”, Telegraph für Deutschland 7/8, 49-52, 57-59, retrieved from Gutzkow Editionsprojekt: https://projects.exeter.ac.uk/gutzkow/Gutzneu/gesamtausgabe/Abtei1/DDtUebe.htm1 839).

Hauff, Wilhelm (1827) Die Bücher und die Leserwelt (Wuppertal: Gerettete Schriften Verlag, Kindle 2013).

Heise, Ursula (2014/5) (ed.) ACLA Report on the State of the Discipline 2014-2015, online at: $<$ http://stateofthediscipline.acla.org $>$

Johnson, Samuel (1753) “All dare to write, who can or cannot read", The Adventurer No. 115 (Tuesday, 11 December), 343.

König, Dominik von (1977) “Lesesucht und Lesewut”, Buch und Leser: Vorträge des 1. Jahrtreffens des Wolfenbütteler Arbeitskreises für Geschichte des Buchswesen, 13. und 14. May 1976, ed. by in Herbert G. Göpfert (Hamburg: Hauswedell Verlag), pp. 89-124.

Littau, Karin (2006) Theories of Reading. Books Bodies and Bibliomania (Cambridge: Polity Press). 
— (2011) "First Steps towards a Media History of Translation", Translation Studies $4.3,261-81$.

— (2016) “Translation's Histories and Digital Futures", Special Section on "Babel and Globalization: Translating in the 21st Century", ed. by Paolo Sigismondi, International Journal of Communication 10, 907-928, online at: $<$ http://ijoc.org/index.php/ijoc/article/view/3508/1571>

Mani, Venkat (2011) "Bibliomigrancy: Book Series and the Making of World Literature", The Routledge Companion to World Literature, ed. by Theo D'haen, David Damrosch and Djelal Kadir (London: Routledge), pp. 283-296.

McMurran, Mary Helen (2010) The Spread of Novels. Translation and Prose Fiction in the Eighteenth Century (Princeton, NJ: Princeton University Press).

Mundt, Theodor (1832) "Deutsche Literatur im Auslande. Goethe in Italiänischem Gewande. - Bürger”, Magazin für die Literatur des Auslandes 127 (Montag 19. November), 505-507.

[Murray, J.] (1886) "Books and Reading", Quarterly Review, 162. 324 (April), 501518. 
Nicolai, Friedrich (1799) Leben und Meinungen des Herrn Magisters Sebaldus

Nothanker. Band I. Vierte verbesserte Auflage (4 ${ }^{\text {th }}$ improved edition) (Berlin: Friedrich Nicolai).

Piper, Andrew (2009) Dreaming in Books. The Making of the Bibliographic Imagination in the Romantic Age (Chicago: The University of Chicago Press).

Pizer, John (2007) “Towards a Productive Interdisciplinary Relationship: Between Comparative Literature and World Literature" The Comparatist 31 (May), 6-28.

Plate, Liedeke (2015) "How to Do Things with Literature in the Digital Age: Anne Carson's Nox, Multimodality, and the Ethics of Bookishness", Contemporary Women's Writing 9.1 (March), 93-111.

Pressman, Jessica (2014) Digital Modernism. Making it New in New Media (Oxford: Oxford University Press).

- (2014/5) "Electronic Literature as Comparative Literature" (published online 28 June 2014), ACLA Report on the State of the Discipline 2014-2015, ed. Ursula Heise.

Sack, Warren (2005) "Public Space, Public Discussion and Social Computing", Working Papers Series, Center on Organizational Innovation, Columbia University, online at http://www.coi.columbia.edu/pdf/sack_pspdsc.pdf, 
Saussy, Haun (2006) "Exquisite Cadavers Stitched from Fresh Nightmares: Of

Memes, Hives, and Selfish Genes", Comparative Literature in the Age of

Globilization, ed. by H. Saussy (Baltimore: The Johns Hopkins University Press), pp. $3-42$.

- (2011) "Interplanetary Literature" in Comparative Literature 63.4, 438-447.

Shand, Alexander, Innes (1879) "Contemporary Literature, VII: Readers", Blackwood's Magazine 126 (August), 235-256.

Spivak, Gayatri (2003) Death of a Discipline (New York: Columbia University Press).

Strich, Fritz (1949) Goethe and World Literature, trans. C.A.M Sym (London: Routledge).

Swales, Martin (1987) Goethe: the Sorrows of Young Werther (Cambridge: Cambridge University Press).

Tabbi, Joseph (2010) "Electronic Literature as World Literature; or, The Universality of Writing under Constraint", Poetics Today 31.1, 17-50. 
Thomas, Sue (2008) “Transliteracy and New Media", Transdisciplinary Digital Art: Sound, Vision and the New Screen, ed. by Randy Adams, Steve Gibson, Stefan Müller Arisona (Berlin: Springer, 2008), pp. 101-109.

Walkowitz, Rebecca (2013) "Close Reading in an Age of Global Writing", $M L Q$ $74.2,171-195$.

- (2014/5) "Future Reading" (published online 30 January 2015), ACLA Report on the State of the Discipline 2014-2015, ed. Ursula Heise.

Watson, Peter (2010) The German Genius (London: HarperCollins).

\section{Notes}

${ }^{1}$ I am thinking here of Christian Morgenstern's phonetic poems.
${ }^{2}$ Liu's notion of transliteracy project is predominantly concerned with online reading,
see website: $<$ http://liu.english.ucsb.edu/transliteracies-research-in-the-technological-
social-and-cultural-practices-of-online-reading/>; I am using Thomas's definition (2008: 101).

${ }^{3}$ See Littau, "Translation's Histories and Digital Futures", Special Section on "Babel and Globalization: Translating in the 21st Century", ed. by Paolo Sigismondi, International Journal of Communication 10 (2016), 907-928, online at:

$<$ http://ijoc.org/index.php/ijoc/article/view/3508/1571>

${ }^{4}$ See Bachleitner (1989: 1-49).

${ }^{5}$ Arac makes this point, in the main, with reference to Marx and Engel's use of the word Verkehr in their conception of world literature (2007: 21).

${ }^{6}$ Berman (1992: 55) is echoing a point made by Fritz Strich.

${ }^{7}$ In this context, see Mani's concept of "bibliomigrancy" (2011).

${ }^{8}$ Their work can be read/seen online at: http://www.yhchang.com

${ }^{9}$ See onlinehttps://people.ucsc.edu/ wsack/TranslationMap/UsersManual/ for a User's Manual.

${ }^{10} \mathrm{See}<\mathrm{http}: / /$ translationmap.walkerart.org/index.html $>$

${ }^{11}$ See $<$ http://translationmap.walkerart.org/how.html $>$

${ }^{12} \mathrm{See}<\mathrm{http}: / /$ www.southbankcentre.co.uk/whatson/the-spectacular-translationmachine-1000392>

${ }^{13}$ See $<$ http://translationgames.net $>$ 